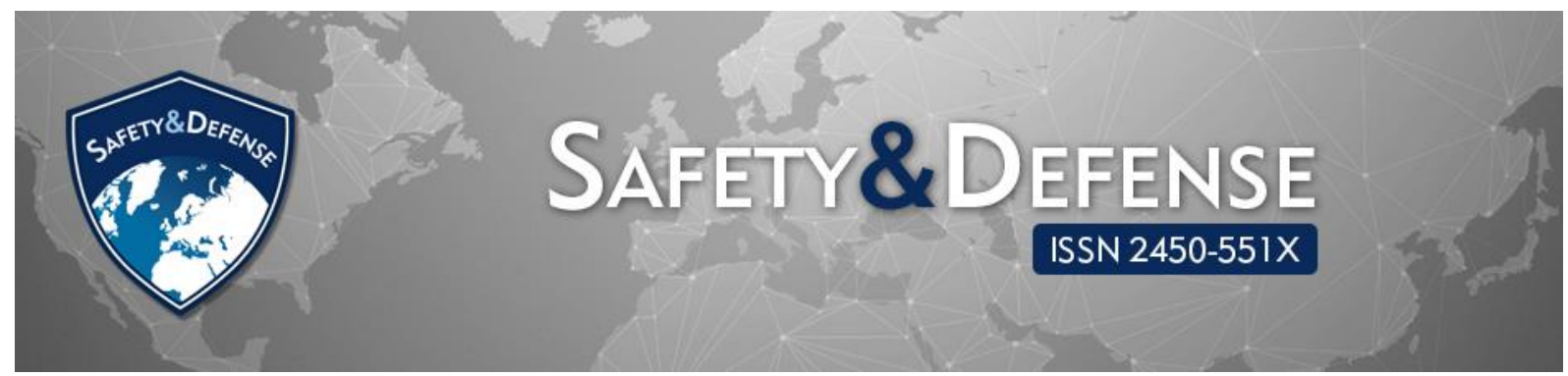

\title{
Irregular Warfare and Modern Defense - Counterinsurgency Operations
}

\section{Irmina DENYSIUK}

War Studies University, Warsaw, Poland, i.denysiuk@akademia.mil.pl, ORCID: oooo-0oo2-1154-5167

DOI: https://doi.org/10.37105/sd.71

\begin{abstract}
Nowadays, there are a lot of dangers, not only those related to the military. Particular attention should be paid to the threat of guerrilla activity. Therefore, the aim of this article is to indicate the essence of contemporary guerrilla operations in conflicts, and their methods of operation that allow them to achieve their goals. It was also assumed that the modern crisis response operations, and especially COIN (counterinsurgency) operations, constitute a comprehensive approach to counteracting guerrilla activity. This article uses theoretical methods. Using the analysis and synthesis of materials and studies, the most important conclusions were pointed out.

The leading role in prevention insurgency activities lies with the United Nations, the North Atlantic Treaty Organization and their crisis response operations. In the Strategic Concept NATO 2010 specialists are putting more attention to conducting counterinsurgency operations (COIN). COIN operations are nowadays the most comprehensive tool for combating guerrilla activity, which mainly hits the civilian population. The concepts of using the assumptions of anti-Partisan operations should be implemented on a full scale, including in the armed forces of the Republic of Poland.

Particular attention should be paid to the threat of the guerrilla activity in conflicts. These problems are complex and they deal with many aspects (social, economic, cultural, political and many others). Moreover the partisans activities are irregular and they are often targeted at civilians. This article indicates the methods and techniques used by insurgents in the fight against the state / government. Reference has also been made to the activities that inhibit their activity - complex counterinsurgency operations.
\end{abstract}

Keywords: defense, insurgency, counterinsurgency operations (COIN), modern warfare, irregular warfare 


\section{The idea of modern insurgent activities}

Many conflicts and crises are characterized by a high degree of irregularity. Insurgent activities use the methods and forms of irregular combat to achieve the goals. The phenomenon of globalization and universal access to information means that the insurgents can also use the latest technology to fight. Nowadays, it is very important to gain and develop the ability of COIN, which should be taken from the past experience of counterinsurgency, and also from the presence of coalition forces in Afghanistan, operating in the first four years of the war (20022006). From the analyzes of insurgency activities in this country are relevant. It appeared that the main objectives of their attacks are primarily the structure of the state and the civilian population then - attacks on the intervening forces (Jones, S.G. (2008). p. 53, Denysiuk, I. (2015). Ewaluacja..., p. 173, Marszałek, M., Denysiuk, I. (2011). Koncepcja..., pp. 28-37).

Guerrilla activities are defined as organized, often ideologically motivated actions taken by irregular groups whose aim is to change the political balance of power in the region or to prevent such change. On the other hand, insurgent actions focus on the abuse or violence of civilians. Such actions are part of irregular activity which is defined as the use or threat of using force by an irregular groups. Often irregular activities are ideologically or criminally (under the influence of warlords) motivated to do or not to do something. That is a challenge for the management of their rebellion against the legitimate authority (AJP 3-4.4. (2011). p. 215.).

Currently, experts point out the close connections between rebellion and terrorism and criminal activities. Any rebellion creates favorable conditions for terrorist and criminal groups. The environment is in fact unstable, weakened, often characterized by a large submission of society. However, insurgents seek ways and terrorist methods to support the achievement of their assumed objectives.

Such complex activities of an irregular character threaten all aspects of society, from the political and economic to legal and organizational functioning of the authorities and government state (AJP 3-4.4. (2011). p. 2-16). There are possibilities that guerillas could have endless influence on civilians. On the other hand, three main capabilities should be noted, which are used in their fight. They are mentioned in detail in the Allied Counterinsurgency Operations Doctrine AJP 3-4.4 as: intellectual, physical and moral (AJP 3-4.4. (2011). pp. 2-17-2-19).

The intellectual abilities of guerrilla groups means developing their own doctrine of action, based on the Islamic law, religious or traditional customs. It is also important for these groups to recruit their followers who will be ready to practice their assumptions recorded in the doctrine. It cannot be excluded that the intellectual manifestation of insurgents activities is based on the past experience, not only their own actions, but also those which are today the basis of classical ideas of irregular actions, and other resources available on the web even if they are interpreted by the strategy of NATO and other organizations and states (USA) (AJP 34.4. (2011). p. 2-17).

This aspect of insurgent activities is also reflected in the creative use of information and informative technology to achieve more extensive knowledge. The guerrillas, by using contemporary technology, refer to the instruments of propaganda by controlling behavior of local community. They undermine the legitimacy of local authorities and penetrate other countries in search of external support for their activities among groups of emigrants. The key element of these activities is to appeal to a common cultural circle and ideology.

The another group of capability - defined as physical, is the most primitive way, 
but is the most popular and simple in practice. The activity of insurgent groups is generally unable to overcome the force of their opponents and therefore, they use asymmetric methods. The groups of insurgents take the enemy by surprise at a critical time and place, gaining advantage over not only tactically but also mentally. The guerrillas do not look for ways of winning in direct combat. Their long-term strategy is such that they can just survive and cause the greatest loss for their opponents.

Physical abilities give the largest range of possibilities and they are closely interrelated with each other, so you can distinguish among them:

- Mental interaction - which is a special tool of fighting between weaker and a stronger, sometimes with the use of primitive techniques. Mental interaction causes not only physical destruction, but it also intensifies panic. Insurgents choose their targets in the urban environments, and focuses on the civilian population. They expect to win renown in the media.

- Formal and informal methods of financial supporting their actions - constitute the power of the guerrilla movement all over the world and obtain the support of charitable organizations, non-governmental and private sponsors, as well as business people.

- Structuralization - creating a vast criminal network which will join not only the rebels, but also terrorists and activists together, not necessarily taking the form of a hierarchical relationship. This indicates that they are independent, and highly mobile, which ensures their anonymity. The insurgent groups, particularly those operating in an urban environment, have the opportunity to influence on the local community, providing them with protection, financial, logistical and mental support.

The last group of insurgent abilities is their motivational techniques often by using measures of social persuasion and/or controlling both the civilian population and individual citizens. The motivation is a complex process, but usually refers to the cultural context. The rebels promise society physical, material and spiritual safety in return for their subordination to them. The insurgents proclaim the need for change in the status quo of the state, by offering their own alternative government. The motivation the community takes different forms, which rebel groups want to keep in a state of instability and injustice to increase dependency and subordination of the civilian population. Currently, the rebels operate in Afghanistan, Iraq and African countries where so-called civil wars take place. Partisan activities are also visible in contemporary internal crises, including in Syria and Ukraine.

\section{Insurgent activities and strate- gies of action}

To achieve their goals, insurgents need an ability which was described in the first section of this article. In addition, experts point out that the insurgents use the following five instruments described as:

- violence (violent actions may take different forms, including military action, terrorism and riots),

- national and international propaganda,

- social support for a society,

- social and political activism,

- international relations (cooperation with other terrorist groups and other actors) (AJP 3-4.4. (2011). Annex B, p. B1).

Today, insurgents have developed different methods to achieve their goals. These methods take the form of well-established strategies now. In Annex B, experts emphasize that insurgents used following strategic models of their activities. That could be distinguished as: 
- conspiratorial,

- military-focused,

- urban approach,

- protracted popular warfare,

- identity-focused,

- composite and alliances (AJP 3-4.4.

(2011). Annex A, pp. A-1-A-6).

The number and variety of these strategies emphasize a complex and comprehensive approach to insurgent activities (Smith, M.L.R., Jones, D.M. (2015). p. 1424-1425).

Firstly - the conspiratorial approach involves a rebellion and the situation, in which a few leaders or militants are trying to take over control of government structures. Normally, such insurgents stay in secret for as long as possible and they emerge as soon as their success is almost at hand. The conspiratorial approach is usually created with a small and secretive group of forces.

The military-focused approach tries to create revolutionary possibilities of achieving their goals. By applying military force, insurgents try to fight for independence or secession. Normally, they can use conventional forces. In the complex environment of operations, they try to employ armed elements to support their seize power. This support can be created with urban or/and rural society. The authors of AJP 3.4.4. say that "this approach was applied in the 6os and $70 \mathrm{~s}$ and it is currently used in some parts of Sub-Saharan Africa" (AJP 3-4.4. (2011). Annex A, p. A-1).

The next - urban approach - is focused on urban terrorism as a long-term activity which is taken by small and independent groups that do not need the support of the common people. This creates that countering them is very difficult. However, insurgents can gain popular support in certain times and areas, especially when there is a close relationship with religion, family or social groups. In urban society, the activities of insurgents and their impact on a population can be more effective.

The protected popular warfare is an approach of insurgents, where decisive combat is intentionally avoided. The main goal in this strategy is seizing political power in a given region. The examples of this approach are those found in the Republic of China or Vietnam in the 2oth century. For example, Mao Zedong created a theory of war which contained a civil-military approach. The complex Mao Zedong's strategy included three phases: latent strategic defensive, strategic balance and strategic offensive.

The identity-focused approach is created on the basis of common identity of clan, tribe, religious or/and ethnic structure. It should be very strongly noted that this approach is most popular among contemporary insurgents. The operations conducted by them would be in the future based on the civil-military actions, more civil - less military. It is very important to get public support, and this is the easiest way to build it just referring to common values.

The composite strategy is the most extensive operation strategy which can be used by insurgents. Nowadays, insurgents use different ways and methods. They know that the best strategy is to take advantage of the moment. These also rely on experiences, not only their own. This approaches assume that there can be many different groups with competing interests in the operational environment.

Contemporary insurgent groups look for ways to maximize its survivability and to establish their own influences in a given state. This is very complicated for counterinsurgency operations. Both the soldiers and the experts (also NATO planners) must understand this type of insurgent strategy to win. Victory must be based on the analysis of all the factors (Marszałek, M. (ed.). (2013). Zintegrowany..., p. 42, Denysiuk I., 2015. pp. 85-106).

Today, insurgencies develop very complex scenarios of actions. There are many actors in the operations environment. It is very hard to clearly separate the two opposing sites: insurgents and forces of opposition. It is crucial that all sites in operation are not uniformed. It is not also easy to distinguish 
them from others: "among these actors are militias, warlords, organized crime, drug dealers, private security companies, NGOs[1], the media, multinational companies, and foreign countries with strategic interests in the area" (AJP 3-4.4 (2011). Annex A, p. A-6).

The nature of contemporary insurgencies is complex. The experts emphasize that different groups of insurgents, also in different countries, can cooperate. There is the possibility of insurgents sharing their experiences. Fighters can take part in other wars. They can also train each other or only give logistic or financial support. It can be stated that today's insurgencies are characterized by an ability to adapt their strategies and rules of action to contemporary challenges of war.

The threats posed by new insurgencies affect countries, which are stricken by the rebellion and other (third) countries. Summarizing, it should be emphasized that there are many types of insurgencies which have different strategies and forms. Modern insurgency is the result of globalization (Jackson, P. (2019), pp. 1-3). Nowadays, insurgents use a new technology like the GPS. They often take a sort of terrorism actions or use tools to impact on society, for example propaganda. They have connections with criminal groups which support their actions in financial and ideological ways. The most comfortable environment for their operations is in the urban area.

We can also name the main motivation methods which are used by insurgents (AJP 3-4.4. (2011). Annex C, pp. C-1-C-2):

- persuasion,

- coercion,

- provoking disproportionate reaction,

- foreign support,

- apolitical motivation.

1 Non-Governmental Organizations - added by author (I.D.).
These motivation methods are the main reasons why insurgent movements are not seen as criminal.

\section{Modern counterinsurgency operations}

The counterinsurgency action theory has been developed since the mid-twentieth century and its main representatives are: David Galula and Roger Trinqier. The strategists have created the foundation of counterinsurgency operations based on their own experience gained during the war in Algeria. The study highlights the general assumptions of counterinsurgency operations and their history. Such operations were conducted, among others, in Indochina, Vietnam (Galula, D. (2006). Trinquier, R. (2006)).

The form of actions which could effectively counter the activities of the rebels are the operations against insurgents (COIN counterinsurgency operations) as a process to respond to crises and conflicts outside the NATO treaty area. This form of fighting counter guerrilla groups, known as "operation other than a war", is therefore desirable.

Counterinsurgency operations are a relatively new tool, particularly in comparison with the older guerilla warfare, are used in non-military activities. The irregular actions are already well established in theory and practice. However, the counterinsurgency operations (COIN) are still developing. It is therefore important to develop the ability of COIN, which is now emphasized in the New Strategic Concept For the Defense and Security of The Members of the North Atlantic Treaty Organization - "Active Engagement, Modern Defense”. 
As already mentioned, "New Strategic Concept ..." experts said that to be more effective across the spectrum of emergency response activities, we should develop abilities such as military abilities required to conduct expeditionary operations, with particular emphasis on counterinsurgency operations, stabilization operations and reconstruction operations (Active Engagement, Modern Defence. (2010), point 25). On the other hand, the U.S. Army Gen. George W. Casey Jr. said, that the armed forces of this country need the ability of counterinsurgency operations, containing of both offensive, defensive and stability actions (Caramone, J. (2010)). Taking into account the activity guerrillas, it is considered that COIN operations should be used and applied in practice not only optional, as one of many possibilities, but they must become an element of necessary actions.

Counterinsurgency operations (COIN) is separated from a set of military operations different from war implemented the stabilization phase, which should be understood as complex, multi-functional and multi-faceted projects, including both military operations conducted by coalition forces targeted against guerrillas and the process of statebuilding to support and help people (Ucko, D.H. (2009)). COIN includes psychological and information operations, intelligence and support to the local community (Marszałek, M., Denysiuk, I. (2013). Elementy..., pp. 1216).

Counterinsurgency operations are aimed at all hostile groups in any state where they are needed. In the records of the "Department of Defense Dictionary of Military and Associated Terms" COIN is military, paramilitary, political, economic, psychological action taken against insurgents (AJP 102. (2001). p. 105). COIN operations are comprehensive civilian and military efforts covering a wide range of activities from fighting with guerrillas to ensure security of the civilian population (Read more: RuffStahl, H.J. (2015). pp. 137-148).

The essence of COIN operations is connected by joint effort of the host countries, international agencies, different other organizations and forces of coalition (JP 3-24. (2009). p. X). It is also pointed out today that victory in war is largely based on the work with the local community, recognizing indigenous government and its security forces (if any). It is a critical value for the success of COIN (Jones, S.G. (2008), pp. 725, Denysiuk, I. (2015), pp. 207-210). The suppression of acting guerrillas depends on the preparation and modernization of the armed forces of intervening. The success will be depend on understanding the nature of local conflicts, the community's needs and the ability of guerrillas. The key to success in the fight against the insurgency is cooperation with society that knows the area of operations, knows the clans, and is able to move in the environment of operation. The local society can contribute to the activities of the coalition partners by providing them with relevant information, including the location of shelters and trails the guerrillas (Marszałek, M. (ed.). (2013). p. 11, Denysiuk, I. (2015), pp. 89-93).

The fundamental strategy of COIN gives assistance in maintaining the legitimate authority and minimizes attacks of guerrilla groups, mainly by trying to isolate those groups, and thus reduces the possibility of impacting them. The COIN effort can repel enemy attacks through the development of a defense system of the failed state (Marszałek, M., Denysiuk, I. (2013). Elementy..., pp. 17-19). ${ }^{2}$

Counterinsurgency operations act on two levels:

- political - as an attempt to reach a peace agreement, assuming that the dispute was created at the level of ideological and cultural, or from a sense of injustice,

\footnotetext{
${ }^{2}$ It is the process of Security Sector Reform (SSR).
} 
- and military - the use of force to enforce the desired behavior. Hence, there is a real need for cooperation on these two levels (Marszałek, M., Denysiuk, I. (2011). Koncepcja..., p .13, Galula, D. (2017). p. 17).

There is a claim that COIN operations depend on: the simultaneous conducting offensive operations (against guerrillas, for example, to take control of at least one area which was previously controlled by the guerrillas), defense (protecting the civilian population, which manifests itself in taking control in major population centers) and stabilization.

There are different theories of COIN operations: today recognized as historic methods: carrot and stick, fight for the hearts and minds and transformation (Marszałek, M., Denysiuk, I. (2011). Koncepcja..., p. 13). The first refers to the correct choice of the system of rewards and punishments, which in practice are applied to manipulate a population. The second i way leads to gaining the confidence of the civilian population. The third is the most extensive approach to COIN, including the practical implementation of such projects as: the transformation of political and economic, and building a better future.

However, the new solutions to prevent insurgent actions are sought today. The nature of guerrilla warfare, which had been many times emphasizing, is difficult and complex. Therefore, the planned approach to COIN operations should include synchronized, multi-faceted activities, including civil-military cooperation, based on a foundation of information and psychological operations (JP 3-24. (2009). p. X-1).

A fundamental role of COIN operations is their information operations. They are addressed to two audiences: civilian and insurgents. Society is informed of the need to demonstrate their support for an operation. The aim is to increase awareness of the population that the coalition forces (U.S. forces) are conducting activities directed exclusively against the rebels (partisans). The messages sent to the rebels urges them to stop irregular activities.

The existence of many methods to achieve success in COIN operations was assumed, wherein these methods are not mutually exclusive and may be used simultaneously. The only criterion for selecting specific strategies for COIN operations is the degree of its adequacy to the needs and conditions in the area of operations. It is necessary to conduct an interview in the local community and select the appropriate strategy. Nowadays, there are three main strategies of counterinsurgency operations:

1 clear-hold-build,

2 combined action,

3 limited support (JP 3-24. (2009). pp. $\mathrm{X}-2-\mathrm{X}-14$, The U.S. Army and Marine Corps Counterinsurgency Field Manual. (2007). p. 174, Marszałek, M. Denysiuk, I. (2011). Koncepcja..., pp. 92-103).

The correct choice of strategy is implemented at the level of the operational planning process. It was pointed out that effective planning COIN operations requires a focus on both combat and non-combat activities. It is also important to distinguish the goals of both personal (detection and elimination the guerrillas) and non-personal (detection hiding places, Information operations).

Choosing the right strategy for COIN operations is based on the level of operations planning. Operational goals are set accordingly for each field of COIN operations, according to the so-called logical lines of operations (LLO) and at every level of activity. Both planning and management of the COIN operation is very complex and requires the involvement of many resources, ranging from intelligence activities, obtaining information (also HUMINT) about the enemy, its leaders, commanders, external support, bases, finances, media and local authorities. (degree of rule of law, democratization, development of security forces and basic government institutions and agencies, degree of provision of relevant services to society, de- 
gree of economic development). All these elements combine the operations environment and information operations as the foundation of all COIN projects. The success of COIN is largely based on the use of strategic communication tools, including psychological operations (PSYOP), information activities (IOs), in the form of action counter ideology, counter-sanctuary, counter - motivation of partisans or propaganda. In order to combat insurgent actions, one must understand the values of their ideology or religion. In addition, COIN efforts must understand the environment and culture of insurgent movements. This allows us to successfully carry out activities under such operations as: counteracting radical ideology, motivating partisans, also motivated by religion. For the purposes of the COIN operation, key recipients, leaders, and authorities are identified in order to know who to reach with information. In COIN operations, the world should be viewed from a local perspective. Comprehensive efforts made by a group of specialists, the media, finance, business and other consultants, including psychologists, are key. (Paul, Ch., Clarke, C.P., Grill, B. (2010). pp. 56-57, Denysiuk, I. (2014)).

In current forms of conducting military operations, including COIN, disinformation is extremely important (both propaganda and so-called fake news - although so far there are no reliable research results indicating the long-term effectiveness of their use). (Świerczak, M. (2018). p. 210).

Disinformation is an extremely complex method of operational work, which is a way of influencing the current or potential opponent, enemy special services or specific groups or social strata in foreign states, but sometimes also one's own country. It is a deliberate transfer of false information to the opponent, using means and methods of operational work in order to mislead him and obtain planned results that are beneficial for him (Polmar, N., Allen, T.B. (2000). p. 151., Lewandowski, H. (2000). p. 81-82.).
COIN strategies should be designed to protect the population against insurgent violence as well as strengthen the legitimacy and potential of government institutions. Therefore, since 2000 in COIN operations, the leading role has been played by groups of theoreticians and practitioners who, with their work, support the success of COIN operations based on information they obtain from civil sources (HUMINT) or through intelligence (SIGINT).

\section{Summary}

Nowadays, it is very important to gain and develop the ability of COIN. Many conflicts and crises are characterized by a high degree of irregularity. Today, the insurgents have developed different methods to achieve their goals. These methods have taken the form of well-established strategies. The number and variety of these strategies emphasize a complex and comprehensive approach to insurgent activities.

Contemporary insurgent groups look for ways to maximize their survivability and to achieve their own influences on the state. This is very complicated for counterinsurgency operations.

COIN operations are comprehensive civilian and military efforts covering a wide range of activities from fight with guerrillas to ensure security of the civilian population. The success of COIN will be depend on understanding the nature of local conflicts, the community's needs and the ability of guerrillas. The key to success in the fight against the insurgency is a cooperation with society that knows the area of operations, knows the clans, and is able to move in the environment of operation. It existence of many methods to achieve success in COIN operations was assumed. There are three main strategies of counterinsurgency operations: clear-hold-build, combined action, limited 
support. The correct choice of strategy is implemented at the level of the operational planning process.

The suggestions contained in this article have helped us to formulate following conclusions:

- the internal conflicts, especially ethnic, religious and national, will become more frequent;

- those conflicts will be dominated by the rebels who are using irregular forms of fights;

- civilians are and they will be the most affected group;

- it is possible to react to these conflicts by NATO forces, the United Nations and coalitions of states;

- it is important to train the armed forces and adjust their ability to adapt to the irregular nature of threats;

- the most crucial matter is civilians support (fight for the hearts and minds) so that it will benefit them, not the rebels;

- counterinsurgency operations reduce the terrorism.

In addition, we have noted that:

- an appropriate way of responding are counterinsurgency operations, which include civil-military cooperation rather than military operations;

- the reaction should take place in many areas, not only military but political, social and economic as well;

- the training system of forces should be expanded, also in the Polish Armed Forces;

- the civilians' participation in the operations should be taken into account;

- these changes must be considered during the planning stage of COIN operations;

— an important element on which COIN operations are based are information operations, psychological ops and other operations as part of strategic communication.
In summary, we have to control the counterinsurgency actions in a methodical way, not just intuitively.

\section{References}

1. Active Engagement, Modern Defence. (2010). Strategic Concept for the Defence and Security of The Members of the North Atlantic Treaty Organization - Adopted by Heads of State and Government in Lisbon, Lisboa

2. AJP 1-02. (2001). Department of Defense Dictionary of Military and Associated Terms

3. AJP 3-4.4. Annex A - Strategies of insurgency

4. AJP 3-4.4. Annex B - Insurgent activities for achieving their goals

5. AJP 3-4.4. (2011). Allied Joint Doctrine for Counterinsurgency (COIN), NATO Standardisation Agency

6. Caramone, J. (2010). Casey says Army needs counterinsurgency capabilities, "American Forces Press Service", Washington, Retrieved from http://www.defense.gov/news/newsarticle.aspx?id=59067, 25.02.2012

7. Cohen, E., Crane, C., Horvath, J., Nagl, J. (2017). Principles, Imperatives, and Paradoxes of Counterinsurgency, [in:] Bett, R.K (ed.), Conflict After the Cold War. Arguments on Causes of War and Peace, New York: Imprint Routledge. DOI:

https://doi.org/10.4324/978131523137 2

8. Crane-Seeber, J. (2011). Everyday Counterinsurgency, "International Political Sociology", Vol. 5, Issue 4, pp. 450-453,

DOI: https://doi.org/10.1111/j.17495687.2011.00145_3.x

9. Denysiuk, I. (2015). Ewaluacja operacji przeciwpartyzanckich, rozprawa doktorska, Warszawa: AON 
10. Denysiuk, I. (2014). Modelowanie kryteriów sukcesu operacji przeciwpartyzanckich, praca naukowo-badawcza , nr III.1.1.o., Warszawa: AON

11. Galula, D. (2006). Counterinsurgency Warfare. Theory and Practice, PSI Classics of the Counterinsurgency Era, Praeger Security International, Westport, Connecticut, London

12. Galula, D. (2017). Insurgeny and Counterinsurgncy [in:] Bett, R.K (ed.), Conflict After the Cold War. Arguments on Causes of War and Peace, New York: Imprint Routledge. DOI: https://doi.org/10.4324/978131523137 2

13. Gompert, D.C., Gordon IV, J., Grissom, A., Frelinger, D.R., Jones, S.G., Libicki, M.C.,, O’Connell, E., Lawson, B.S., Hunter, R.E. (2008). War by other Means. Building Complete and Balanced Capabilities for Counterinsurgency, RAND Counterinsurgency Study - Final Report, Santa Monica: Rand Corporation

14. Jackson, P. (2019). Intelligence in a modern insurgency: the case of the Maoist insurgency in Nepal, "INTELLIGENCE AND NATIONAL SECURITY", https://doi.org/10.1080/02684527.201 9.1589677, DOI: 10.1080/02684527.2019.1589677

15. Jones, S.G. (2008). Counterinsurgency in Afghanistan, RAND Counterinsurgency Study, Vol.4, RAND Corporation

16. JP 3-24. (2009). Counterinsurgency Operations, Joint Chiefs of Staff

17. Lewandowski, H. (2000). Podstęp, inspiracja i dezinformacja $w$ działalności stużb specjalnych, Warszawa

18. Marszałek, M., Denysiuk, I. (2011). Koncepcja użycia sił zbrojnych $w$ wojnach nieregularnych, praca naukowobadawcza nr III.5.1.o, Warszawa: AON

19. Marszałek, M., Denysiuk, I. (2013). Elementy wsparcia procesu stabilizacji $i$ odbudowy państw, „Zeszyty Naukowe”, no 4(9)
20.Marszałek, M. (ed.). (2013). Zintegrowany system budowy planów zarządzania kryzysowego $w$ oparciu o nowoczesne technologie informatyczne, Projekt badawczo-rozwojowy w zakresie obronności i bezpieczeństwa państwa finansowany ze środków Narodowego Centrum Badań i Rozwoju, Warszawa

21. Paul, Ch., Clarke, C.P., Grill, B. (2010). Victory has a thousand fathers. Sources of Success in Counterinsurgency, RAND Corporations

22. Pechenkina, A.O., Bennett, D.S. (2017), Violent and Non-Violent Strategies of Counterinsurgency, "Journal of Artificial Societies and Social Simulation”, Vol 20, Issue, SimSoc Consortium, DOI: 10.18564/jasss.3540

23. Polmar, N., Allen, T.B. (2000). Księga szpiegów. Encyklopedia, Warszawa

24. Ruff-Stahl, H.J. (2015). Human Factors im Krieg: Ist COIN eine taktische Antwort auf ein strategisches Problem?, [in] Schroeder, R., Hansen, S. (ed.) Stabilisierungseinsätze als gesamtstaatliche Aufgabe, Erfahrungen und Lehren aus dem deutschen Afghanistaneinsatz zwischen Staatsaufbau und Aufstandsbewältigung (COIN), DOI: https://doi.org/10.5771/978384524901 8-137

25. Smith, M.L.R., Jones, D.M. (2015). The political impossibility of modern counterinsurgency: strategic problems, puzzles and paradoxes, International Affairs, Vol 91, Issue 6, https://doi.org/10.1111/14682346.12467

26. Świerczak, M. (2018). System matrioszek, czyli dezinformacja doskonata. Wstęp do zagadnienia, „PRZEGLĄD BEZPIECZEŃSTWA WEWNĘTRZNEGO" no 19

27. The U.S. Army and Marine Corps Counterinsurgency Field Manual. (2007). Chicago and London: The University of Chicago Press 
28. Trinquier, R. (2006). Modern Warfare. A French View of Counterinsurgency, PSI Classics of Counterinsurgency Era, Praeger Security International, Westport, Connecticut. London

29. Ucko, D.H. (2009). The New Counterinsurgency Era. Transforming the U.S. Military for Modern Wars, Washington 